\title{
A Comparison of Socially Responsible and Islamic Equity Investments
}

\author{
G. Forte \\ Università degli Studi di Milano-Bicocca \\ E-mail: gianfranco.forte@ unimib.it \\ F. Miglietta \\ Università degli Studi di Bari 'Aldo Moro \\ E-mail: f.miglietta@disag.uniba.it
}

\begin{abstract}
Defining social investing and its boundaries is a challenging task, since no general consensus exists about the 'ideal' characteristics that socially responsible investments (SRIs) should possess. Some faith-based investments, for instance, Islamic funds, are often associated with SRIs, even if there are some inconsistencies in the investment decisions. This paper explores whether Islamic investments can be included into the category of SRIs or whether they exhibit characteristics that would more fittingly classify them in a separate investment family. To answer this research question, we focus on equity investments from both a qualitative and a quantitative point of view. The first part of the study discusses and compares the screens generally used to build socially responsible (SR) and Islamic portfolios, while the quantitative section of our study analyses portfolios' characteristics using relevant European indices as a proxy for SRI and Islamic funds. Covering the period from 2001 to 2011, we use style analysis to investigate the sector and country composition of SR and Islamic portfolios. In addition, through a cointegration analysis on FTSE indices, we show that the econometric profile of the FTSE Islamic series exhibits peculiar portfolio characteristics compared to conventional and SRI indices. Although the academic literature has extensively analysed SRIs and some authors have focused on Islamic investments, to the best of our knowledge, this is the first paper to investigate the qualitative and econometric differences between SRIs and Islamic investments.
\end{abstract}

Keywords: Style analysis, socially responsible investments, cointegration analysis, Islamic investments, Islamic mutual funds

JEL Classification Codes: G12, G23, P43

\section{Introduction}

To introduce ethics and religion into investments is both a challenging task and a difficult issue to overcome. Business ethics scholars are unable to precisely define social investing, and attempts to identify what falls within this ambit can lead to different answers (Dunfee, 2003). The term socially responsible (SR), just like ethical and sustainable, are very often used as synonyms and many different criteria are applied to categorise ethically screened investments. Moreover, since religious movements were among the first investors to introduce screens in their portfolios, faith-based investments share the 
same roots as SRIs and are often associated with and even assimilated by them. Our study focuses on a particular kind of faith-based investment, namely, Islamic investments, whose rules are based on total adherence to Shari'ah (Islamic law), which prohibits the charging of interest (riba), uncertainty in contracting (gharar), and pure speculation (maisir).

Though SR and Islamic investors may be interested in different screening criteria, the idea of excluding companies according to a set of ethical constraints is of mutual interest (Wilson, 1997). Thus, this research analyses the screens imposed on SR and Islamic investments and compares the characteristics of the resulting portfolios, both qualitatively and quantitatively. Since differences exist between managing equity and bond portfolios, we focus on equity portfolios, which are, in terms of assets under management, more important.

To address our research question, on the one hand, we need a reliable and comprehensive definition of the term SRI. On the other hand, we must take into account the complexity of Islamic law, since many issues in investing (e.g., derivatives) can be interpreted differently, depending on the Islamic jurisprudential school. Our qualitative section analyses the main investment strategies applied in the screened portfolios and discusses fund management issues. Basing our reasoning on an ideal archetype of SR and Islamic funds, we discuss the similarities and differences between SR and Islamic investments. We conclude that Islamic investments, since they are faith based, are to some extent different from SRIs. This comparison relies on the European Social Investment Forum (Eurosif) for definitions of social responsibility that are widely known and accepted among academics and practitioners. For Islamic rulings, we refer to the jurisprudence of the Islamic Fiqh Academy, an authoritative body of the Islamic commercial jurisprudence, and to that of some eminent Shari'ah scholars (i.e. M.T. Usmani and M.A. Elgari).

To address the research question more in depth, the second part of our study performs an empirical analysis of two European equity portfolios, socially responsible and Islamic (proxied by relevant European indices), to assess 1) sector and country composition characteristics (through a style analysis) and 2) differences in econometric profiles (through a cointegration analysis of FTSE SRI and Islamic indices). Our findings corroborate qualitative considerations, since we find that Islamic portfolios and SRIs exhibit different behaviours. This insight could be interesting for investors who want to diversify their portfolios.

As detailed in the following Section II, in the case of both SRI and Islamic investments, most research focuses on performance. Our study, instead, disregards performance and compares the filters used in portfolio construction to determine intrinsic style and econometric peculiarities. Our dual approach, both qualitative and quantitative, allows us to unify research results on the general features of SRIs (Cooper and Schlegenmilch (1993); Cowton (1994); Benson et al. (2006); Hellsten and Mallin (2006)) with the results from available studies on the institutional background of Islamic investments (Naughton and Naughton (2000); Elgari (2002); Usmani (2002)) and their investment style. Even though SRI studies are common in academia, this is the first time, to the best of our knowledge, that SR investments are compared with Islamic investments.

The remainder of the paper is organised as follows. Section II reviews the relevant literature about SR and Islamic investments. Section III presents and discusses the screens applied to SR and Islamic portfolios and Section IV compares the resulting portfolios. Section V exhibits the results of a standard style analysis on the more relevant SRI and Islamic European indices, whose econometric profiles are analysed in Section VI. Section VII presents our conclusions.

\section{Review of the literature}

Since accepting a responsibility beyond maximising profits can impose a burden on returns, as argued by the Nobel laureate Milton Friedman (1970), many researchers focus their research interest on SRI performance, determining whether SRI funds perform worse than common funds because of less diversification and/or sector exclusion. The performance of ethically screened portfolios and the link between financial investments and ethical concerns was first analysed by Grossman and Sharpe (1986) 
when, in response to apartheid, US social movements tried to persuade churches and charities to divest from South African stocks. In the following decades, many studies (Luther et al. (1992); Hamilton et al. (1993); Gregory et al. (1997); Orlitzky et al. (2003); Bauer et al. (2005)) focused their analysis on ethical funds, comparing their performance with that of conventional funds. Summing up, the researchers' evidence suggests that SRI and conventional funds perform similarly in terms of financial returns, and the results indicate that the hypothesis of SRI fund underperformance due to a lack of diversification can be rejected; however, SRI funds do not add value in terms of performance.

Besides activist social movements, churches and religious groups started to screen investment portfolios according to well-defined faith-based prescriptions, as in the Islamic case. There is not yet a rich literature documenting Islamic fund behaviour and performance, although Hakim and Rashidian (2004) focus on Shari'ah indices (as an investment proxy) and find that the application of Islamic filters creates an Islamic portfolio that has a lower risk and higher Sharpe ratio than conventional indices. Furthermore, the authors' Islamic index has a much lower level of interest rate sensitivity than its conventional counterpart. Also Hussein (2005) studies Islamic and conventional indices and finds that, from a statistical point of view, their performance are not different. Elfakhani et alt. $(2005,2007)$ focus on mutual funds and verify that the behaviour of Islamic investments does not differ from that of conventional investments. Recently, Hoepner et al. (2010) studies the investment style of 265 Islamic equity funds and find that Islamic funds are often 'growth' portfolios and show a preference for smallcap stocks.

\section{Screens Applied to SR and Islamic Investments}

In the last few years, SRIs have been rapidly developing in Europe. The movement was originally born during the 1920s in the UK, when the Methodist Church established an investment policy of avoiding 'sinful stocks' (Sparkes, 2002). By the 1960s, this financial moralist movement had started to spread to the rest of Europe, as churches and religious groups attempted to place their financial investments in line with their views and principles. In the beginning, those investments filtered according to religious schemes were defined as 'ethical', since, from a religious point of view, ethics and faith are strictly linked. Nowadays, however, religious investment schemes are instead referred to as 'faith-based', while the terms ethical and $S R$ have more of a layperson's connotation. These last two terms are often used interchangeably, the former being typically used in some parts of the world, as in the UK, Canada, and Australia, and the latter term, for example, in the US (Hellsten and Mallin, 2006).

Cowton (1994) defines ethical investments as those that make use of ethical and social criteria in the selection and management of investment portfolios. On this basis, many authors have tried to establish a comprehensive definition of SRIs; however, this is not a simple task, and business ethicists have not reached a general consensus, since the world of ethical investments and definitions associated with it is greatly influenced by the cultures of various countries. While religious criteria were originally used, they have been supplanted at times by environmental strategies, anti-war projects, and human rights activism (Sparkes, 2002).

The definition of SRI provided by Eurosif (2010) states that 'socially responsible investments combine investors' financial objectives with their concerns about environmental, social, and governance (ESG) issues (p.8)'. The emphasis on financial performances is clearly stated: There is no social investment without financial soundness. Even if, in theory, investors are willing to sacrifice some performance to reach social goals that they consider important, the performance of ethical funds is very much a concern, as in the case of any financial investment (Wilson, 1997).

To create a 'typical' European equity SR portfolio, we rely on Eurosif's 2010 definition above, according to which an SRI's investment philosophy can be summarised as follows: (1) Concern with long-term investment exists and (2) long-term investment performance must be reached in accordance with ESG issues. To compose such a portfolio, asset managers use several investment strategies, which are detailed in Table 1. 
Table 1: Definition of an SRI and the most common European strategies.

BASE DEFINITION: SRI is a generic term covering any type of investment process that combines investors' financial objectives with their concerns about ESG issues.

\begin{tabular}{|l|l|l|}
\hline $\begin{array}{c}\text { Segmentation } \\
\text { of SRI }\end{array}$ & \multicolumn{1}{|c|}{ STRATEGYS } & \multicolumn{1}{c|}{ Definition } \\
\hline Core SRI & $\begin{array}{l}\text { Norm /value- } \\
\text { based exclusions } \\
\text { Best in class }\end{array}$ & $\begin{array}{l}\text { Negative screening of companies according to their compliance with international } \\
\text { standards and norms (e.g., the United Nations Global Compact). } \\
\text { Approach where the leading companies with regard to ESG criteria from each } \\
\text { individual sector or industry group are identified and included in the portfolio. } \\
\text { Thematic funds based on ESG issues such as the transition to sustainable } \\
\text { development and a low-carbon economy. May focus on sectors such as water and } \\
\text { energy. } \\
\text { An approach that excludes a given sector from a fund (e.g., arms manufacture, } \\
\text { pornography, tobacco, and animal testing). } \\
\text { Engagement is applied by some fund managers to encourage more responsible } \\
\text { business practices and/or enhance investment returns. It relies on the influence of } \\
\text { investors and the rights of ownership and mainly takes the form of a dialogue } \\
\text { between investors and companies on issues of concern. Engagement can extend to } \\
\text { voting practices. } \\
\text { Integration is the explicit inclusion by asset managers of ESG risk factors into } \\
\text { traditional financial analysis. }\end{array}$ \\
\hline
\end{tabular}

Source: Eurosif $(2006,2010)$.

Negative criteria, as in simple exclusion and norm/value-based exclusions (where 'negative' sectors and stocks are excluded from the portfolio menu) were initially very common and are still very popular in Nordic countries and in Italy and Belgium. At present, asset managers use more complex strategies, such as best in class, used largely, for example, in France and Finland. In Europe, SRI assets managed according to these criteria total about 5 trillion Euros (of which about $33 \%$ are equity funds), representing about $10 \%$ of all managed assets. Approximately $92 \%$ of these assets belong to institutional investors, mainly pension funds, universities, insurance firms, and, to some extent, charities and churches (e.g., Methodists, Quakers, Presbyterians, and Anglicans) (Eurosif, 2010). It is worth observing that the Eurosif database includes religious investments in the SR world, and there is no distinction between social movements and religious groups. In addition, SRIs are growing in importance in the US, where assets managed according to SR strategies reached, at the start of 2010, $\$ 3.07$ trillion, $12.2 \%$ of total assets under management in the US (Social Investment Forum, 2010). Unlike in Europe, in the US and Canada many concerned investors promote engagement, allowing investors to file and vote on shareholder resolutions focused on social and environmental concerns.

Due to the additional research costs associated with SR in-house stock selection, engaging in these investment strategies can be an expensive and time-consuming undertaking. Therefore, SR funds use as a benchmark, in asset management, SR indices composed of a set of securities created according to clear, predefined criteria. To create an SR index, researchers start from a conventional universe of assets and apply specific filters to derive a universe of eligible assets. A number of highly diversified equity indices invest in the assets of different geographical areas, for example, the Dow Jones Stoxx sustainable indices, the Domini social indices, and the FTSE4Good indices. In the case of FTSE4Good, for instance (in which the universe of eligible constituents is drawn from the FTSE Developed Index), inclusion criteria relate to (1) environmental management, (2) climate change mitigation and adaptation, (3) countering bribery, (4) upholding human and labour rights, and (5) supply chain labour standards. The fourth item is of particular concern to those companies having businesses in countries where human rights are frequently violated, such as Angola, Egypt, Congo, Cuba, Iran, Saudi Arabia, Syria, and Zimbabwe. In addition to inclusion criteria, some sector-specific exclusion criteria have been added, concerning, namely, the marketing of breast milk substitutes, uranium mining, and nuclear power (FTSE, 2008). Some funds and index providers ask the guidance of an 'ethical committee' 
composed of the eminent representatives of charities, non-governmental organisations, and supranational bodies, whose opinions, although important, are intended only as advice.

Jointly with SRIs, we study Islamic investments, whose fundamentals derive from the Islamic law, or Shari'ah, which constitutes a part of every Muslim's cultural and spiritual identity (DeLorenzo, 2002). These laws are based largely on the Qur'an (the holy book of Muslims) and the Sunnah (the practices of the Prophet Muhammad) and 'are to be followed in letter and spirit (p. xiii)' (Usmani, 2002). The Qur'an not only contains moral teachings but also offers guidance in all aspects of life, including any socioeconomic behaviour: Religion is, thus, a fusion of life's temporal and spiritual aspects. Islam differs from the other two major monotheistic religions - Christianity and Judaism - by its lack of division between religion and state (Baldwin, 1990).

Islamic economy does not deny profit, private ownership, or market forces, but they are not allowed in total freedom and must be observed in accordance with divine prescription. In this context, money is only a mean of exchange: It cannot be used as an asset and may not generate a profit. At the same time, it cannot be left unproductive, since hoarding is not allowed under Shari'ah. Charging interest on money loaned (riba), regardless of the rate imposed, is explicitly prohibited: Riba encompasses every form of exploitation in business conduct and the concept is not restricted to charging interest but also applies, for instance, to the promise of remuneration with a predefined rate of return (Naughton and Naughton (2000); Iqbal and Mirakhor (2007)). Another basic element of Islamic finance relates to the prohibition of risk and uncertainty: Any sort of ambiguity in contracting (i.e., uncertainty as to the quantity, quality, deliverability, or existence of the asset) is referred to as gharar and is prohibited (Fadeel, 2002). Pure speculation is also forbidden. All the prohibitions combined have the ultimate and cumulative effect of preserving balance, distributive justice, and equal opportunity and must always be honoured in any Islamic transaction (Usmani, 2002). Although Islamic law is intended as imperatives for every man, some aspects of economic transactions remain in debate and depend on the schools of jurisprudence, which can differ in their rulings on a given issue. The four major Sunni schools of law or jurisprudence (madh'hab) are the Maliki, Hanafi, Shafi'i, and Hanbali.

Due to difficulties in complying with religious prescription, Islamic financial markets have been characterised for a long time by the use of very basic financial instruments. Beginning in the 1980s, however, to serve the more sophisticated financial needs of high net worth individuals living in the Gulf area, the most prominent Islamic institutions started to widen their range of financial instruments. Islamic asset management funds were born in this period. Although still in their infancy, these managed funds have the potential to play a pivotal role in financial markets, since Muslims constitute about $20 \%$ of the world population (Girard and Hassan, 2006). Investors entering Shari' ahcompliant investments, particularly Islamic mutual funds, are increasing by about 12-15\% per year, and the global Islamic fund management industry reached total assets under management of $\$ 52$ billion (Ernst \& Young, 2010). The major players in the asset management of Islamic investments are, among others, primary Western investment houses, such as UBS, Schroders, HSBC, and Deutsche Bank, that are trying to attract Muslim retail investors (Cox, 2002).

Before detailing the Islamic equity investment process and the filters used, it is important to acknowledge that, to be valid under Shari'ah, investments must abide by two basic conditions (Usmani, 2002): First, no fixed return can be promised or obtained, that is, the profit must be strictly linked to the performance of the companies whose stocks are in the portfolios. The second binding condition refers to the inclusion of Shari'ah-compliant securities in the portfolios. Ideally, we can split the Islamic equity investment criteria into three distinct classes, all ruled by religious prescription: (1) portfolio asset allocation, (2) instruments and trading strategies, and (3) income distribution and purification.

1) In portfolio asset allocation, the starting menu of stocks is to be screened according to religious prescription. The manager sets up industry and financial ratio screens to ensure the final portfolio's compliance to Shari'ah. The industry screens relate to the main activity of a company and its revenue allocation. First, its main activities must be halal: All banks and insurance companies whose activities are interest based are screened out, as well as all 
companies involved in alcohol, tobacco, armaments manufacturing and trading, and the entertainment business. Second, even when they belong to legitimate sectors, companies are examined on the basis of their revenue allocation. If a company has business activities, for example, in breweries, defence, or pork related products, it is considered inappropriate for Islamic investment purposes and must be excluded from the portfolio. Furthermore, if the business is halal but the company borrows money on interest or deposits its surpluses into interest-bearing accounts, the Moslem shareholders have a moral duty to file resolutions in the general assembly to publicly condemn this behaviour (Usmani, 2002). This is a form of shareholder activism, as in the SR case. After these industry filters are applied, all remaining stocks are analysed on the basis of financial ratio screens related to debt, interest-bearing securities, and receivables and cash. The total outstanding debt divided by trailing 24-month average market capitalisation must not exceed the threshold of 33\%, and the same rule applies to the sum of cash and to accounts receivables, divided by trailing 24-month average market capitalisation (Dow Jones, 2010). Some index providers calculate such financial ratios dividing by total assets and not market capitalisation, aiming to avoid excessive volatility (MSCI Barra, 2010). The emphasis placed on debt, interest-bearing securities, and receivables clearly stems from the avoidance of riba. The prohibition of hoarding, however, is the basis for the condemnation of excessive cash (Elgari, 2002).

2) As for the instruments and trading strategies, once it is decided which companies can be included in the portfolio, the fund manager must comply with the rules related to the portfolio management activity. For example, certain practices associated with stock trading are not permitted, such as short selling and margin trading. Furthermore, some instruments, such as preferred stocks and interest-based bonds, are forbidden. In addition, dealing in foreign exchange is strictly prohibited. The use of derivatives, as well, faces severe restrictions, since forward contracts, standard future contracts on commodities and on stock indices, are not permitted. Options are deemed permissible only in some cases (Al-Bashir, 2001 and 2008). To overcome the prohibition related to derivatives, some innovative compliant structures have been developed, but a discussion of their structure is beyond the scope of this study.

3) The third category (income distribution and purification) is typical of a Shari'ah-compliant investment. When included in portfolios, partially 'interest-contaminated' balance figures are to be cleansed or purified. Once managers identify what is not acceptable from a Shari'ah point of view, they should deduct from the returns the prohibited part of the earning.

All Islamic instruments issued on financial markets and lists of acceptable securities to be included in portfolios are supervised by an independent body of specialised jurists in Islamic commercial jurisprudence, called Shari'ah Board. A Shari'ah Board, whose ruling is binding, has the twofold role of certifying the compliance of any stock traded according to Shari'ah and ensuring that the portfolio is able to create value for its shareholders. Though establishing a Shari'ah Board is very common in order to obtain a 'compliance' certificate, those funds not willing to establish one can delegate all relevant decisions to the Islamic indices, that provide a Shari' ah-compliant menu of stocks already screened by eminent scholars.

\section{The Qualitative Analysis}

This section defines ideal archetypes of equity Islamic investments and SR equity investments to compare their portfolios. We thus rely on Table 2, which first states the general goals of the two portfolios and then summarises the screens commonly used (and detailed in Section III). 
Table 2: $\quad$ Key characteristics of SR and Islamic investments.

\begin{tabular}{|c|c|c|}
\hline & ISLAMIC INVESTMENT & SRI \\
\hline Final Aim & $\begin{array}{l}\text { The betterment of all society; this } \\
\text { cannot be reached without strict } \\
\text { compliance to all Shari'ah } \\
\text { prescriptions. }\end{array}$ & $\begin{array}{l}\text { To attain this requires a sustainable economic system } \\
\text { that takes into account ESG effects. }\end{array}$ \\
\hline $\begin{array}{l}\text { Clear definition of action } \\
\text { limits }\end{array}$ & $\begin{array}{l}\text { Yes, the guide is the Qur'an, } \\
\text { integrated when possible with } \\
\text { legal interpretations. }\end{array}$ & $\begin{array}{l}\text { No, a universally recognised definition of social } \\
\text { responsibility does not exist. A common definition is } \\
\text { the ESG definition. }\end{array}$ \\
\hline Faith-based rules & Yes. & No. \\
\hline Supervisory committee & $\begin{array}{l}\text { Yes, a Shari'ah supervisory board } \\
\text { whose opinions are binding. }\end{array}$ & $\begin{array}{l}\text { Yes, an ethical committee, whose opinions have the } \\
\text { status of advice. }\end{array}$ \\
\hline Management strategy & & \\
\hline - Sector/industry exclusion & $\begin{array}{l}\text { Yes, sectors considered not } \\
\text { compliant with the Qur'an are } \\
\text { excluded. }\end{array}$ & $\begin{array}{l}\text { Yes, sectors not compliant with social and } \\
\text { environmental criteria are excluded. }\end{array}$ \\
\hline - Best in class & $\begin{array}{l}\text { No, there is a general distinction } \\
\text { between admissible and } \\
\text { prohibited assets. The strategy is } \\
\text { in-out. }\end{array}$ & $\begin{array}{l}\text { Yes, firms operating in sectors generally forbidden } \\
\text { can be included if they exhibit a commitment to SR } \\
\text { principles. }\end{array}$ \\
\hline $\begin{array}{l}\text { - Screens based on } \\
\text { environmental filters }\end{array}$ & No & Yes \\
\hline $\begin{array}{l}\text { - Screens related to the human } \\
\text { rights }\end{array}$ & ( & 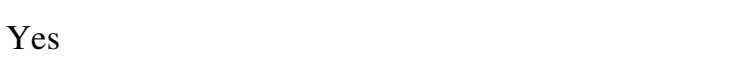 \\
\hline $\begin{array}{l}\text { - Screens associated with } \\
\text { transparent corporate practices }\end{array}$ & No & 然 \\
\hline - Country exclusion & No & $\begin{array}{l}\text { Yes, countries where human rights are violated and } \\
\text { companies having business in such countries are on } \\
\text { the watch list of many indices providers. }\end{array}$ \\
\hline - Shareholder advocacy & $\begin{array}{l}\text { Sometimes. Shareholders are } \\
\text { encouraged to formally express } \\
\text { negative opinions regarding } \\
\text { compliant practices. } \\
\text { Yes, some financial instruments }\end{array}$ & Yes, mostly used in US and Canadian markets. \\
\hline $\begin{array}{l}\text { Restriction on investment } \\
\text { activities and instruments }\end{array}$ & $\begin{array}{l}\text { (e.g., preferred stock) and } \\
\text { investment activities are } \\
\text { forbidden. }\end{array}$ & No \\
\hline Financial ratio screens & $\begin{array}{l}\text { Yes, financial ratio filters based } \\
\text { on religious prescription are } \\
\text { applied during the selection } \\
\text { process. The core principles on } \\
\text { which the filters are based relate } \\
\text { to leverage, the presence of } \\
\text { interest-bearing assets and } \\
\text { liabilities, and high levels of debt } \\
\text { and receivables. }\end{array}$ & $\begin{array}{l}\text { There are no financial predefined parameters that } \\
\text { determine the inclusion of an asset in the SRI index. } \\
\text { The fund manager decides which ratios or financial } \\
\text { characteristics are required to include a stock in the } \\
\text { managed portfolio. }\end{array}$ \\
\hline
\end{tabular}

Concerning the general aims of ethically/religious concerned investments, one can say that in both cases investors aim at a 'better' economic system: In the Islamic world, the most desirable economic system is one shaped according to Shari' ah prescription that guarantees balance, distributive justice, and equal opportunity. In the case of SR funds, however, the final aim is a sustainable economic system that takes into account ESG issues. Islamic scholars stress this similarity: Elgari (2002), for instance, includes Islamic funds in the family of 'ethical funds', stating that the basic concept of Islamic investments is ethical. DeLorenzo (2002) goes further: According to Shari'ah, business must be 'responsible' and 'committed' to good causes, and there is therefore no difference between an ethical fund and an Islamic one. Even though these ideas are intriguing, the inclusion of 
faith-based Islamic funds in the SR family is not straightforward, since a closer look at the second part of Table 2 reveals some potential drawbacks regarding the filters imposed on the portfolios.

- In their management strategy, SR funds are allowed, through the best-in-class approach, to consider 'borderline' companies or sectors and this represents a beneficial addition to the fund diversification strategy. In Shari'ah funds, by contrast, some sectors, such as conventional finance and insurance companies, are excluded tout court, since managers apply an in-out strategy. In addition, it is worth mentioning an essential issue related to human rights and environmental screens: Islamic funds do not apply such screens, while SR investments do, both at the stock level and from a country selection point of view. Should Islamic funds apply some of these SR human rights screens, a potential conflict of interest could arise, since, for instance, some of the countries on the Amnesty International watch list for human rights violations are Islamic. If applied, such negative screens would oblige Islamic asset managers to exclude countries such as Syria, Egypt, Iran, and Saudi Arabia. In Islamic terms, this would be a contradiction or even nonsense: These countries belong to the Ummah (a word that means one community of believers, the whole Islamic world unified) and should therefore be favoured. Furthermore, Shari'ah fund management does not pay attention to environmental issues, which can lead to the inclusion of stocks that, in an SR context, would be screened out for their negative environmental impact.

- Managers of SR funds can use all the trading strategies they deem useful and do not use financial ratio screens derived from religion. Islamic fund managers, however, face specific financial screens (i.e., concerning leverage, the presence of interest-bearing assets, and high levels of receivables and debt) and cannot use margin trading or short sales. Moreover, they are limited in the use of certain financial instruments, such as derivatives.

- The ethical committees of SR asset management houses, when they exist, play a consulting role with no veto power, whereas a Shari'ah Board's decisions are binding for the manager.

One additional important insight relates to the emphasis on performance. In the SR case, the basic goal of sustainability is twofold and considers the profit-seeking process a fundamental part of the investment strategy. In this context, social and environmental screens are as important as financial ones. The SR fund archetype is ultimately characterised by the equal emphasis placed on the attainment of the so-called three P's: people, planet, and profit. In Islamic management activity, however, profit is attainable only when all religious conditions are satisfied. It seems that two layers of importance exist: The first layer includes all religious screens, while the second layer refers to the research of a positive risk-return profile. Although a positive return is of fundamental importance, it is less relevant when compared to religious compliance.

The religious/Islamic and SR universes could converge if shareholder advocacy methods were largely used to promote management practices in line with investor beliefs and ideas. Such a strategy could then lead to more similar portfolios, and the exclusion criteria would become less important. Moreover, Islamic index providers and investors are increasingly concerned about environmental sustainability, which has resulted, for instance, in the creation of the Dow Jones Islamic Market Sustainability Index, which merges Islamic investing principles and sustainability filters, including not only Shari'ah-compliant companies but also corporations acting as sustainability leaders according to best-in-class methods. Should Islamic funds use environmental criteria in the selection of eligible stocks, the two investments we analyse could become more similar in terms of stock and country composition.

\section{Sharpe Analysis: Style, sector, and Country Allocation}

Our empirical analysis concentrates on the major relevant indices for the European market. Applying a standard Sharpe (1992) analysis on monthly frequency, the primary objective is to test the impact of SR as well as faith-based Islamic screens on management style and on the sector and country composition of the most popular SR and Islamic indices. This exercise is not intended to reveal 
statistically significant differences in long-run performance. Indeed, as discussed in Section II, the contraction in the universe of eligible assets does not have a relevant impact on the performance of the portfolios screened. A deeper investigation of the style, sector, and country composition of the indices can provide, however, a useful starting point to assess whether SRI and Islamic funds are to be considered viable alternative investments.

We focus on five relevant European indices, including three sustainability indices (the DJ Sustainability Europe, the DJ Sustainability Europe ex AGTF, and the FTSE4Good Europe), one Islamic index (the DJ Islamic Europe), and a general conventional index (the MSCI Europe). Figure 1 shows that, in the last 10 years, these indices have performed similarly but with relevant sub periods of under/over performance between them.

Figure 1: The four indices in the long run.

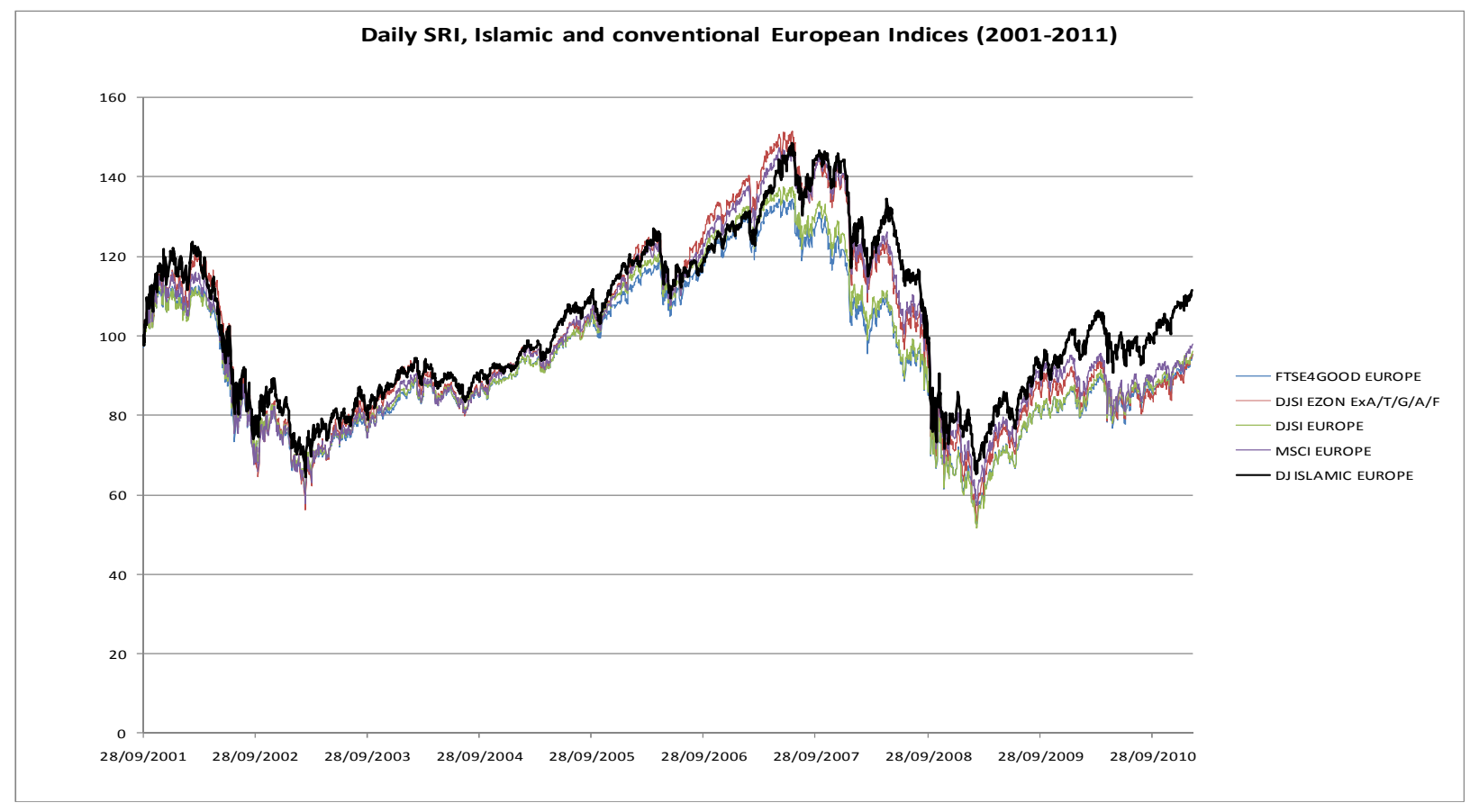

The first part of Table 3 offers some interesting insight regarding the investment styles of the indices under analysis. We use the European Dow Jones STOXX Total Market Indices (TMI) to track our portfolios' behaviour. Over the period "31 September 2001 to 31 January 2011", the sustainable indices are all more value than growth, as well as the general MSCI Europe Index. However, the DJ Islamic Europe signals a strong preference for growth stocks, with value factor accounting for only $32 \%$ of the portfolio. This preference may reflect the exclusion of financials (which are generally value stocks) from Shari'ah-compliant portfolios, signalling, on the other hand, possible overweighting for sectors that follow a growth profile over the period considered, including, for instance, industrials, consumer goods, health care, and consumer services. In terms of size, Islamic stock selection does not neglect mid-cap stocks, unlike the general behaviour of the sustainable indices. The MSCI shows, instead, a more balanced approach in terms of portfolio size composition, although tilted toward large stocks, as imposed by a capitalisation weighting scheme. 
Table 3: Sharpe analysis: Style, sector, and country composition.

\begin{tabular}{|c|c|c|c|c|c|}
\hline & $\begin{array}{l}\text { FTSE4Good } \\
\text { Europe }\end{array}$ & $\begin{array}{l}\text { DJ ex AGTF } \\
\text { Europe }\end{array}$ & $\begin{array}{c}\text { DJ Sustainability } \\
\text { Europe }\end{array}$ & $\begin{array}{c}\text { MSCI } \\
\text { Europe }\end{array}$ & $\begin{array}{l}\text { DJ Islamic } \\
\text { Europe }\end{array}$ \\
\hline $\begin{array}{c}\text { Monthly Obs. \# (31/09/2001- } \\
\text { 31/01/2011) }\end{array}$ & 112 & 112 & 112 & 112 & 112 \\
\hline \multicolumn{6}{|c|}{ STYLE ANALYSIS } \\
\hline (Total Market Index) TMI Growth & $47 \%$ & $19 \%$ & $43 \%$ & $32 \%$ & $68 \%$ \\
\hline TMI Value & $53 \%$ & $81 \%$ & $57 \%$ & $68 \%$ & $32 \%$ \\
\hline (R squared) $R^{2}$ & $99 \%$ & $93 \%$ & $98 \%$ & $95 \%$ & $91 \%$ \\
\hline (Tracking error) $T E$ & $0.59 \%$ & $2.05 \%$ & $0.76 \%$ & $1.49 \%$ & $1.74 \%$ \\
\hline TMI Large & $94 \%$ & $79 \%$ & $94 \%$ & $86 \%$ & $77 \%$ \\
\hline TMI Mid & $6 \%$ & $21 \%$ & $6 \%$ & $14 \%$ & $23 \%$ \\
\hline TMI Small & $0 \%$ & $0 \%$ & $0 \%$ & $0 \%$ & $0 \%$ \\
\hline$R^{2}$ & $99 \%$ & $94 \%$ & $99 \%$ & $96 \%$ & $90 \%$ \\
\hline$T E$ & $0.41 \%$ & $2.13 \%$ & $0.60 \%$ & $1.52 \%$ & $1.85 \%$ \\
\hline Large-Cap Growth & $39 \%$ & $5 \%$ & $38 \%$ & $21 \%$ & $41 \%$ \\
\hline Mid-Cap Growth & $6 \%$ & $10 \%$ & $4 \%$ & $4 \%$ & $27 \%$ \\
\hline Small-Cap Growth & $0 \%$ & $8 \%$ & $0 \%$ & $9 \%$ & $4 \%$ \\
\hline Large-Cap Value & $53 \%$ & $77 \%$ & $56 \%$ & $66 \%$ & $27 \%$ \\
\hline Mid-Cap Value & $2 \%$ & $0 \%$ & $3 \%$ & $0 \%$ & $0 \%$ \\
\hline Small-Cap Value & $0 \%$ & $0 \%$ & $0 \%$ & $0 \%$ & $0 \%$ \\
\hline$R^{2}$ & $99 \%$ & $93 \%$ & $98 \%$ & $95 \%$ & $91 \%$ \\
\hline$T E$ & $0.52 \%$ & $1.99 \%$ & $0.68 \%$ & $1.44 \%$ & $1.71 \%$ \\
\hline Aut\&Prt & $2 \%$ & $7 \%$ & $2 \%$ & $6 \%$ & $0 \%$ \\
\hline Banks & $18 \%$ & $13 \%$ & $19 \%$ & $11 \%$ & $0 \%$ \\
\hline Bas Res & $1 \%$ & $0 \%$ & $2 \%$ & $0 \%$ & $5 \%$ \\
\hline Chem & $8 \%$ & $16 \%$ & $10 \%$ & $14 \%$ & $19 \%$ \\
\hline Cns\&Mat & $0 \%$ & $4 \%$ & $0 \%$ & $6 \%$ & $5 \%$ \\
\hline Fd\&Bvr & $3 \%$ & $0 \%$ & $3 \%$ & $0 \%$ & $0 \%$ \\
\hline Fin Sves & $4 \%$ & $0 \%$ & $3 \%$ & $0 \%$ & $0 \%$ \\
\hline Hea Care & $12 \%$ & $0 \%$ & $14 \%$ & $0 \%$ & $2 \%$ \\
\hline Indus Gd & $0 \%$ & $0 \%$ & $1 \%$ & $0 \%$ & $1 \%$ \\
\hline Insur & $8 \%$ & $23 \%$ & $10 \%$ & $16 \%$ & $2 \%$ \\
\hline Media & $4 \%$ & $0 \%$ & $0 \%$ & $1 \%$ & $0 \%$ \\
\hline Oil\&Gas & $9 \%$ & $5 \%$ & $8 \%$ & $4 \%$ & $17 \%$ \\
\hline Pr\&Ho Gd & $4 \%$ & $0 \%$ & $9 \%$ & $1 \%$ & $9 \%$ \\
\hline Retail & $7 \%$ & $0 \%$ & $3 \%$ & $0 \%$ & $0 \%$ \\
\hline Tech & $7 \%$ & $14 \%$ & $4 \%$ & $11 \%$ & $23 \%$ \\
\hline Telecom & $10 \%$ & $0 \%$ & $10 \%$ & $9 \%$ & $2 \%$ \\
\hline Trv\&Lsr & $0 \%$ & $0 \%$ & $0 \%$ & $0 \%$ & $0 \%$ \\
\hline Util & $4 \%$ & $18 \%$ & $2 \%$ & $21 \%$ & $16 \%$ \\
\hline Real estate & $0 \%$ & $0 \%$ & $0 \%$ & $0 \%$ & $0 \%$ \\
\hline$R^{2}$ & $100 \%$ & $98 \%$ & $99 \%$ & $99 \%$ & $96 \%$ \\
\hline$T E$ & $0.32 \%$ & $1.00 \%$ & $0.48 \%$ & $0.73 \%$ & $1.18 \%$ \\
\hline \multicolumn{6}{|c|}{ COUNTRY ALLOCATION } \\
\hline Msci Italy & $9 \%$ & $10 \%$ & $5 \%$ & $11 \%$ & $0 \%$ \\
\hline Msci Germany & $13 \%$ & $48 \%$ & $21 \%$ & $26 \%$ & $9 \%$ \\
\hline Msci Finland & $2 \%$ & $5 \%$ & $1 \%$ & $5 \%$ & $12 \%$ \\
\hline Msci Denmark & $0 \%$ & $0 \%$ & $0 \%$ & $0 \%$ & $8 \%$ \\
\hline Msci Switzerland & $7 \%$ & $0 \%$ & $15 \%$ & $1 \%$ & $4 \%$ \\
\hline Msci Spain & $8 \%$ & $13 \%$ & $11 \%$ & $15 \%$ & $0 \%$ \\
\hline Msci Austria & $0 \%$ & $1 \%$ & $0 \%$ & $0 \%$ & $0 \%$ \\
\hline Msci UK & $38 \%$ & $0 \%$ & $32 \%$ & $0 \%$ & $6 \%$ \\
\hline Msci France & $13 \%$ & $1 \%$ & $4 \%$ & $30 \%$ & $48 \%$ \\
\hline Msci Belgium & $0 \%$ & $0 \%$ & $4 \%$ & $1 \%$ & $0 \%$ \\
\hline Msci Netherlands & $6 \%$ & $21 \%$ & $3 \%$ & $10 \%$ & $4 \%$ \\
\hline Msci Portugal & $0 \%$ & $0 \%$ & $0 \%$ & $1 \%$ & $0 \%$ \\
\hline Msci Greece & $0 \%$ & $2 \%$ & $0 \%$ & $0 \%$ & $0 \%$ \\
\hline Msci Sweden & $4 \%$ & $0 \%$ & $4 \%$ & $0 \%$ & $0 \%$ \\
\hline Msci Norway & $0 \%$ & $0 \%$ & $0 \%$ & $0 \%$ & $9 \%$ \\
\hline$R^{2}$ & $99 \%$ & $99 \%$ & $99 \%$ & $100 \%$ & $95 \%$ \\
\hline$T E$ & $0.39 \%$ & $0.85 \%$ & $0.56 \%$ & $0.25 \%$ & $1.29 \%$ \\
\hline
\end{tabular}


This table reports the results of a standard style analysis of five relevant European indices, including three sustainability indices (the DJ Sustainability Europe, the DJ Sustainability Europe ex AGTF, and the FTSE4 Good Europe), one Islamic index (the DJ Islamic Europe), and a general conventional index, a proxy for the global European equity market (MSCI Europe). The estimated exposures to style, sector, and country factors refer to the period September 2001 through January 2011, involving monthly time series (112 observations). To determine the style and sector allocation, we regress the indices on the appropriate Dow Jones STOXX Total Market Indices (TMI). The country composition is obtained using the MSCI country indices as explanatory variables. The weights shown correspond to the average holdings over the corresponding sample period. The bottom rows of each section report the $\mathrm{R}^{2}$ and the tracking error of the constrained regression.

For a deeper understanding, the third section of the Table 3 shows a style analysis using a combination of style (growth/value) and size (small/medium/large) explaining factors. The Islamic index is behaved as a large-cap growth $(41 \%)$ portfolio, with a sensible weight on mid-cap growth (27\%) and large-cap value (27\%) factors. The emphasis on the large-cap growth portion of the portfolio distinguishes the DJ Islamic index from both sustainability and general conventional index.

The middle section of Table 3, showing sector allocation, confirms our intuition about the inclusion/exclusion of some sectors we hinted at when analysing value/growth composition. In this case, we use the DJ STOXX sector indices to track portfolio behaviour. In the DJ Islamic, as expected, financials (including banks, insurance, financial services, and real estate) have zero weight. The sustainability indices, however, are strongly invested in financials (13-19\% in banks and 8-23\% in insurance). Investments in oil and gas show substantial differences: The DJ Islamic is invested in this sector at a rate that is almost double that of the remaining indices (17\% versus 5-9\%). Again, this is not surprising: Islamic countries are the primary producers of oil, and investments in these companies are both permissible and recommended, since they favour the economic betterment of the Ummah. Sustainability indices, on the other hand, apply specific filters on these companies: In a polluting sector, only those companies acting as sustainability leaders can be included in the portfolios. Although Islamic portfolios are heavily skewed towards oil and gas, this is not enough to counterbalance the zero weight on financials; indeed, on average, other sectors such as technology, utilities, and chemicals show higher values when compared to the sustainability indices.

The third section of Table 3 reveals interesting insights about the country allocation of European portfolios. In this case, we use the MSCI country indices to track portfolio behaviour. If we focus on the percentage invested in the German stock market, we can immediately identify a substantial difference in the composition of the indices under analysis. The DJ Islamic underweights the German market and this behaviour is consistent if we perform a robustness check for different time horizons. This result only seems odd; indeed, a closer analysis of sector allocation clarifies the exclusion. As has been shown, financials are zero-weighted in Islamic portfolios, which mean that banks, insurance companies, and financial services (including real estate activities) are screened out. If we proxy the German market with the DAX 30 Index, we can easily see that six out of 30 stocks (as of 31 March 2011) are immediately screened out after a qualitative sector assessment: Allianz, Commerzbank, the Deutsche Bank, and the Deutsche Börse are classified as financial companies; Heidelberg Cement is active in the real estate sector and is financed through debt; and Münchener Ruck is a reinsurance company. The Italian stock index FTSEMIB is also characterised by a sizeable presence (in terms of both capitalisation and number of stocks) of banks and insurance, which can explain the complete absence of this market in Shari'ah portfolios. This same line of reasoning can be applied when explaining a preference for Nordic countries' markets, where industrials, consumer discretionary, and information technologies are well represented.

The differing compositions in terms of styles, sectors, and countries, as discussed, can signal potential divergence in the behaviours of these indices, although no differences can be detected in long-run performance. 


\section{Econometric Profiles: Cointegration Analysis}

In terms of index composition, the results reveal deep differences between Islamic and other indices. Since the polarisation involves simultaneously style, country, and size profiles, we question whether this marked composition difference is somehow able to induce different behaviours for the Islamic index, although not in final performance. We test a divergence hypothesis based on the econometric properties of the indices' price series, going beyond a simple correlation analysis. For robustness, we examine daily time series, with a sample of 1,762 observations from September 2001 to the end of June 2008. ${ }^{1}$ The analysis is limited to FTSE indices and excludes the Dow Jones to control for potential bias introduced by different index construction methodologies.

The FTSE4Good and the FTSE Islamic proxies again for screened portfolios in a SR and Islamic sense. The universe from which both restricted indices select their stocks is the FTSE Developed Europe Index. We investigate whether there is cointegration between sustainability, Islamic, and global indices, as well as interest rates, proxied by the Euribor $3 \mathrm{~m}$. We first perform a standard unit root test (augmented Dickey-Fuller, 1979) ${ }^{2}$ for the four series, and our results clearly reject the null hypothesis of a unit root in the differences, but not in price levels.

We then focus on potential links between the time series over time. The traditional approach is based on correlations of returns; however, this approach cannot identify stable relations. In addition, high levels of correlation can be spurious. Correlations are strongly linked to the samples selected and neglect to consider any association with stochastic trends. We rely instead on the theory of cointegration, discussed in Engle and Granger (1987), and apply the testing procedure developed by Johansen and Juselius (1990). We investigate the cointegration relations between the four series in an overall model, as well as the cointegration considering the series in pairs.

It is natural to question whether linear transformations, other than differencing, will also induce stationarity. The answer is not obvious; unlike differencing, there is no guarantee that the outcome must be stationary $(\mathrm{I}(0))$. Cointegration analysis is designed to find linear combinations of variables that also remove unit roots. In a bivariate context, if $y_{t}$ and $x_{t}$ are both non-stationary in levels (I(1)), there may (but need not) be a unique value $\alpha$, such that $y_{t}-\alpha x_{t}$ is $\mathrm{I}(0)$. In other words, there is no unit root in the relation linking $y_{t}$ and $x_{t}$. Consequently, cointegration is a restriction on a dynamic model and is therefore testable. Cointegration vectors are of considerable interest when they exist, since they determine $\mathrm{I}(0)$ relations that hold between variables that are individually non-stationary. Such relations are often called long-run equilibria, since it can be proven that they act as 'attractors' towards which convergence occurs whenever there are departures from these long-run values.

Because of their stochastic trends, I(1) variables 'wander' (often quite widely), whereas (weakly) stationary variables have constant means and variances; if there exists a linear combination that delivers an $\mathrm{I}(0)$ relation, one might think that it can be clearly detected from graphs of the variables. Unfortunately, in general, these graphs are not straight interpretable. Thus, cointegration may or may not exist among variables that do or do not appear cointegrated; the only way to find out is through careful statistical analysis, and not by relying on visual inspection. These two points, namely, the importance of cointegrated relations but their non-obvious nature, motivate our analysis.

We focus on a vector autoregression (VAR) to describe the system to be investigated. Consider the generic $p$-dimensional VAR model

$$
X_{t}=\prod_{1} X_{t-1}+\cdots+\prod_{k} X_{t-k}+\Phi D_{t}+\varepsilon_{t}
$$

as our point of origin, where the $\varepsilon_{t}$ are assumed to be independent and Gaussian-distributed error terms. The variable $D_{t}$ contains deterministic terms such as a constant, ${ }^{3}$ a linear trend, and seasonal dummies. The error correction form for the model is

\footnotetext{
1 The sample is limited due to the delisting of the FTSE Islamic in June 2008. Other Islamic indices currently available do not have large enough samples to guarantee robustness in the analysis.

2 The results of the test are not reported but are available from the authors upon request.

${ }^{3}$ We discuss later the choice of intercept and trends for model specification.
} 


$$
\Delta X_{t}=\prod X_{t-1}+\sum_{i=1}^{k-1} \Gamma_{i} \Delta X_{t-i}+\Phi D_{t}+\varepsilon_{t}
$$

It is well known that if the characteristic polynomial has all its roots outside the unit disk, then $X_{t}$ is stationary. If the polynomial has one or more unit roots, then $X_{t}$ is an integrated process. A unit root implies that $\Pi$ has reduced rank $r<p$, and if the number of unit roots equals $r-p$, then the process $X_{t}$ is integrated of order one. When $\Pi$ has reduced rank, it can be written as a product of two $p \times r$ matrices, $\Pi=\alpha \beta$ of rank $r$, such that the model can be expressed in the form

$$
\Delta X_{t}=\alpha \beta^{\prime} X_{t-1}+\sum_{i=1}^{k-1} \Gamma_{i} \Delta X_{t-i}+\Phi D_{t}+\varepsilon_{t}
$$

This process can be inverted to an infinite moving average representation, also known as the Granger representation. It should now be evident that a cointegrated VAR provides a rich model. Indeed, the representation shows the following:

- The matrix $\beta$ (cointegration vectors) with the property that $\beta X_{t-1}$ is a stable process that defines an equilibrium relation between the variables in $X_{t}$;

- The adjustment matrix $\alpha$ describes the reaction of the system to the last period's disequilibrium $\beta X_{t-1}$;

- The coefficients of the term $\Delta X_{t-i}$, representing short-term changes resulting from previous changes in the market, which need not have permanent effects on the levels.

For example, if $\operatorname{rank}(\Pi)=0$, then no series of the variables can be expressed as a linear combination of the remaining series. This indicates that no long-run relation exists among the series in the VAR model. As a test of cointegration, a rank of zero means that integration is rejected. On the other hand, if the rank is one or greater, then there exists one or more cointegrating vectors. This indicates a long-run relation, or that the series exhibits significant evidence of behaving as a cointegrated system.

In a multivariate test of cointegration, we are interested in whether there exists at least one cointegrating vector, in other words, whether the rank of the coefficient matrix $\Pi$ is at least one. Thus, if the rank of the matrix is greater than or equal to one, the null of no cointegration will be rejected. We apply a likelihood ratio test ${ }^{4}$ : The null hypothesis (H0) is that the number of cointegrating vectors is $r$, versus the alternative $r=p$. This alternative corresponds to the case where none of the series has a unit root, and thus a stationary VAR may be specified in terms of the levels of all the series. The test is also repeated for $r=0,1, \ldots, p-1$.

The results of cointegration tests may be sensitive to the lag structure chosen. The proper lag profile for the $\operatorname{VAR}(p)$ model may be determined using model selection criteria. The general approach is to fit $\operatorname{VAR}(p)$ models with order $p=0, \ldots, p_{\max }$, and to choose the value of $p$ that minimises some model selection criteria. The two most common information criteria are the Akaike information criterion and the Schwarz Bayesian information criterion, suggesting, in our analysis, to consider six lags, or trading days.

The tests can also be influenced by the specification of the model in terms of constant and trend assumptions. Because we test our variables for unit roots having rejected the hypothesis of (trend) stationarity in favour of unit roots, we exclude a linear trend in the cointegration equation $\left(\alpha \beta^{\prime} X_{t-1}\right)$. The choice of a constant term in the cointegration equation is more appropriate; approximations usually introduce some constant term, for example, due to the use of raw interest rates or because of different units of measurement resulting from the stock indices' construction methodology. For these reasons,

\footnotetext{
${ }^{4}$ The trace statistic reported in Table 3 is computed as $L R_{t r}(r \mid p)=-T \sum_{i=r+1}^{p} \log \left(1-\lambda_{i}\right)$, where $\lambda_{i}$ is the $i$ th largest eigenvalue of
} the matrix $\Pi$. 
we choose to include an intercept in the cointegration equation but not in the $\mathrm{VAR}^{5}$ as our preferred model. ${ }^{6}$

The results in Table 4 are not surprising. The full cointegration system reveals at least two possible vectors of cointegration. We also estimate cointegration systems based on the series in pairs (first considering any index with the Euribor $3 \mathrm{~m}$, and then between the stock indices). First, all three indices under analysis are cointegrated with interest rates. This is not surprising, since the investment philosophy of the FTSE Developed and the FTSE4Good is related to the market as a whole without strict economic restrictions, and market behaviour is influenced by interest rates.

Table 4: Tests for cointegration.

Period: 28/09/2001-30/06/2008, obs. n. $=1,762$

Lags interval (in first differences): 1 to 6

\begin{tabular}{|c|c|c|c|}
\hline $\begin{aligned} \text { Null hypothesis } \mathrm{HO} & =\text { Number of Cointegrating } \\
& \text { Vectors }\end{aligned}$ & Max-Eigen Statistic & $\mathrm{CV}(5 \%)$ & Prob. \\
\hline \multicolumn{4}{|c|}{ Cointegrating System:(FTSEIslamic, FTSE4Good, FTSEDevel., Euribor3m) } \\
\hline None* & 34.184 & 32.118 & 0.0275 \\
\hline At most $1 *$ & 26.346 & 25.823 & 0.0426 \\
\hline At most 2 & 11.772 & 19.387 & 0.4367 \\
\hline At most 3 & 7.396 & 12.518 & 0.3051 \\
\hline \multicolumn{4}{|c|}{ Cointegrating System: (FTSEIslamic, Euribor $3 \mathrm{~m}$ ) } \\
\hline None* & 26.637 & 19.387 & 0.0037 \\
\hline At most 1 & 5.930 & 12.518 & 0.4692 \\
\hline \multicolumn{4}{|c|}{ Cointegrating System: (FTSE4Good, Euribor3m) } \\
\hline None* & 26.749 & 19.387 & 0.0036 \\
\hline At most 1 & 8.489 & 12.518 & 0.2143 \\
\hline \multicolumn{4}{|c|}{ Cointegrating System: (FTSEDevel., Euribor3) } \\
\hline None* & 25.874 & 19.387 & 0.005 \\
\hline At most 1 & 6.403 & 12.518 & 0.4109 \\
\hline \multicolumn{4}{|c|}{ Cointegrating System: (FTSEIslamic, FTSEDevel) } \\
\hline None & 8.351 & 19.387 & 0.789 \\
\hline At most 1 & 1.862 & 12.518 & 0.9765 \\
\hline \multicolumn{4}{|c|}{ Cointegrating System: (FFTSE4Good, FTSEDevel) } \\
\hline None* & 20.642 & 19.387 & 0.0327 \\
\hline At most 1 & 2.844 & 12.518 & 0.8945 \\
\hline \multicolumn{4}{|c|}{ Cointegrating System: (FTSEIslamic, FTSE4Good) } \\
\hline None & 15.255 & 19.387 & 0.1801 \\
\hline At most 1 & 3.960 & 12.518 & 0.7479 \\
\hline
\end{tabular}

${ }^{5}$ Introducing an intercept in the VAR, that is, a constant in the first differences model, means that the non-stationary variables are I(1) and have a drift, which creates a tendency to continuously move either upward or downward. This is not the case in our analysis involving stock indices and interest rates.

${ }^{6}$ If changes in the interest rate are, on average, zero, the hypothesis of a constant average growth rate (risk premium) of stock price indices should lead to comparable levels for the three indices self-compensating in the cointegration vectors, than not requiring a separate constant in the VAR. Nevertheless, the cointegration results are robust to the alternative choice of intercept in the cointegrating equation, as well as in the VAR component. 
This table shows the results of a standard cointegration test on three European stock indices (the FTSE Islamic Europe, FTSE4Good Europe, and FTSE Developed Europe, proxying, respectively, for an Islamic, an SR, and a conventional equity portfolio) and on interest rates for the euro area proxied by the Euribor $3 \mathrm{~m}$. The daily time series refer to the period September 2001 through June 2008 (1,762 observations). The tests apply to seven different cointegrating systems (VAR specifications), starting from a full system including all four series and then considering the six combinations of the series in pairs. Each estimated VAR includes six lags (in first differences) for the variables involved, following the results of a preliminary specification test. The characteristics of the series and the economic meaning of the model lead us to include an intercept in the error correction but not in the VAR section of the cointegrating systems. Here $(*)$ denotes rejection of the null hypothesis at the 5\% significance level.

The FTSE Islamic, notwithstanding the exclusion of stocks fundamentally related to interest rates, such as financials, and the exclusion of all stocks with a balance sheet deeply influenced by interest rates, is influenced by trends in interest rates. The FTSE Islamic and Euribor 3m are cointegrated. Analysing the indices in pairs we see that the FTSE4Good and FTSE Developed are cointegrated, but we cannot reject the null of no cointegration when we pair the FTSE Islamic index with the FTSE Developed and FTSE4Good.

In the first case, the explanation links to the building methodology of the FTSE Developed and FTSE4Good. The latter index derives directly from the FTSE Developed after the application of SR filters; apart from the exclusion of a few sectors, the general philosophy is related to a best-in-class screening that allows the asset manager to choose corporations that intend to become corporate sustainability leaders (see Table 1). So, the two indices, though different, have a common root.

The second finding, related to the FTSE Islamic versus the FTSE Developed and FTSE4Good, is very interesting: the FTSE Islamic is not cointegrated with the SR and the conventional index. The Table 4 shows that the Islamic index possesses a stochastic trend that is not comparable with either of the other two indices. Since our market data indicate that SRI and Islamic portfolios behave differently, this can represent a valuable insight into our research question about their similarity in econometric profile. Furthermore, this could be of interest for an investor seeking to build a diversified portfolio. The relevant peculiarities revealed by the style analysis, due to size and style as well as country and sector allocation, are probably capable to make a stochastic trend not linearly linked to sustainable and general indices.

\section{Conclusions}

This study tests through both qualitative and quantitative methods the differences between Islamic and SRI funds. The first part of the research is a qualitative analysis aimed at determining any differences in the common filters screening SR and Islamic portfolios. We find that SRI and Islamic funds' main goals are similar, since they aim to reach a 'better economic system', though the meaning of the term better differs. While in the case of SRI funds the term pertains to sustainability, social instances, and governance practices, the purpose of Islamic finance is to obtain a world compliant with Shari'ah, the Islamic religious and temporal law. Our in-depth analysis of the screens used to derive the universe of eligible assets further highlights the substantial differences in terms of human rights and environmental screens: Islamic funds do not apply such screens, whereas SR funds consider them to be of fundamental importance. This can result in completely different portfolios, both from a stock and a country selection point of view. We also determine other differences in terms of the importance assigned to returns from investments: Islamic funds place the highest importance on the compliance of eligible assets to Shari' ah, and financial performance, while still important, appears to be secondary. In contrast, SRI funds stress with equal emphasis sustainability, environment, and financial returns.

These insights are confirmed by our style analysis: This quantitative exercise shows that the indices we use as a proxy for SRI and Islamic portfolios are different in terms of country and sector composition. Moreover, our data show that the Islamic index possesses a stochastic trend that is not 
comparable with either of the other two indices since it is not cointegrated with the SR and the conventional indices.

Since we demonstrate that ethical and Islamic funds are different, both qualitatively and quantitatively, our findings could be of interest for an investor willing to build a diversified portfolio. Rebus sic stantibus, our findings could also be useful in defining norm-based funds (Catholic, Islamic, Lutheran, or Methodist) as religious funds or faith-based funds to underscore their religious basis and give investors a clear understanding of the values that characterise the modus operandi of each fund and its potential risk and return profile. These classes of religious investments are, of course, similar to SRIs but have unique and easily distinguishable intrinsic characteristics that would more fittingly classify them in a separate investment family.

\section{References}

[1] Al-Bashir M., 2001, 'The Islamic Bonds Market: Possibilities and Challenges', International Journal of Islamic Financial Services, 3(1), 1-18.

[2] Al-Bashir, M., 2008, Risk Management in Islamic Finance. Brill, Leiden.

[3] Baldwin, D., 1990, 'Turkey: Islamic Banking in a Secularist Context', in R. Wilson (ed.), Islamic Financial Markets. Routledge, New York, pp. 33-58.

[4] Bauer, R., K. Koedijk, and R. Otten, 2005, 'International Evidence on Ethical Mutual Fund Performance and Investment Style', Journal of Banking and Finance, 29, 1751-1767.

[5] Benson, K., T. Brailsford, and J. Humphrey, 2006, 'Do Socially Responsible Fund Managers Really Invest Differently?', Journal of Business Ethics, 65(4), 337-357.

[6] Cooper, C., and B. Schlegenmilch, 1993, 'Key Issues in Ethical Investment', Business Ethics: a European Review, 2(4), 213-227.

[7] Cox, S., 2002, 'Retail and Private Client Services', in S. Archer and R. A. Karim (eds.), Islamic Finance, Innovation and Growth. Euromoney Books and AAOIFI, London, 129-142.

[8] Cowton, C., 1994, 'The Development of Ethical Investment Products', in A. R. Prindl and B. Prodhan (eds.), Ethical Conflict in Finance. Blackwell, Oxford, 213-232.

[9] DeLorenzo, T. Y., 2002, 'The Religious Foundations of Islamic Finance', in S. Archer and R. A. Karim (eds.), Islamic Finance, Innovation and Growth. Euromoney Books and AAOIFI, London, 9-28.

[10] Dickey, D. A., and W. A. Fuller, 1979, 'Distribution of the Estimators for Autoregressive Time Series with a Unit Root', Journal of American Statistical Association, 74, 427-431.

[11] Dow Jones, 2010, 'Guide to the Dow Jones Islamic Market Index', available at www.djindexes.com, last accessed March 2011.

[12] Dunfee, T. W., 2003, 'Social Investing: Mainstream or Backwater?', Journal of Business Ethics, 43, 247-252.

[13] Elfakhani, S., M. K. Hassan and Y. Sidani, 2005, 'Comparative Performance of Islamic versus Secular Mutual Funds', Conference Paper presented at the 12th Economic Research Forum, Cairo, December 19-21.

[14] Elfakhani, S., M. K. Hassan and Y. Sidani, 2007, 'Islamic Mutual Funds', in Hassan, M. K. and Lewis, M. K. (eds.), Handbook of Islamic Banking. Edward Elgar Publishing, Cheltenham, 256-276.

[15] Elgari, M., 2002, 'Islamic Equity Investment', in S. Archer and R. A. Karim (eds.), Islamic Finance, Innovation and Growth. Euromoney Books and AAOIFI, London, 151-160.

[16] Engle, R., and C. Granger, 1987, 'Cointegration and Error Correction: Representation, Estimation and Testing', Econometrica, 55(2), 251-276.

[17] Ernst \& Young, 2010, 'Islamic Funds \& Investments Report 2010', available at www.ey.com, last accessed March 2011.

[18] Eurosif, 2006, 'European SRI Study, 2006', available at www.eurosif.org, last accessed March 2011.

[19] Eurosif, 2010, 'European SRI Study, 2010', available at www.eurosif.org, last accessed March 2011. 
[20] Fadeel, M. N., 2002, 'Legal Aspects of Islamic Finance', in S. Archer and R. A. Karim (eds.), Islamic Finance, Innovation and Growth. Euromoney Books and AAOIFI, London, 90-108.

[21] Friedman, M., 1970, 'The Social Responsibility of Business Is to Increase its Profits', New York Times Magazine, reprinted in T. Donaldson and P. Werhane, 1983, 'Ethical Issues in Business: A Philosophical Approach', 2nd Edition. Prentice Hall, Englewood Cliffs.

[22] FTSE, 2008, 'FTSE4Good Index Series: Factsheet', available at www.ftse.com, last accessed March 2011.

[23] Girard, E., and M. K. Hassan, 2006, 'Faith-Based Ethical Investing: The Case of Dow Jones Islamic Indexes', 2006 Financial Management Association Annual Meeting, Salt Lake City, Utah, October 11-14.

[24] Gregory, A., J. Matatko, and R. Luther, 1997, 'Ethical Unit Trust Financial Performance: Company Effects and Fund Size Effect', Journal of Business Finance and Accounting, 24(5), 705-725.

[25] Grossman, B., and W. Sharpe, 1986, 'Financial Implications of South Africa Divestment', Financial Analysts Journal, 42(4), 15-31.

[26] Hamilton, S., H. Jo, and M. Statman, 1993, 'Doing Well While Doing Good? The Investment Performance of Socially Responsible Mutual Funds', Financial Analysts Journal, 49(6), 62-66.

[27] Hakim, S., and M. Rashidian, 2004, 'Risk and Return of Islamic Stock Market Indexes', presented at the International Seminar of Nonbank Financial Institutions: Islamic Alternatives, Kuala Lumpur, March 1-3.

[28] Hellsten, S., and C. Mallin, 2006, "Are "Ethical" or "Socially Responsible" Investments Socially Responsible?', Journal of Business Ethics, 66, 393-406.

[29] Hoepner, G. F., H. Rammal, and M. Rezec, 2010, 'Islamic Mutual Funds Financial Performance and International Investment Style: Evidence from 20 Countries', European Journal of Finance, forthcoming, available at SSRN: http://ssrn.com/abstract=1475037

[30] Hussein, K. A., 2005, 'Islamic Investment: Evidence from Dow Jones and FTSE Indices', presented at the Sixth International Conference on Islamic Banking and Finance, Jakarta, Indonesia, November 14-21.

[31] Iqbal, Z., and A. Mirakhor, 2007, 'An Introduction to Islamic Finance, Theory and Practice'. John Wiley, Singapore.

[32] Johansen, S., and K. Juselius, 1990, 'Maximum Likelihood Estimation and Inference on Cointegration - With Applications to the Demand for Money', Oxford Bulletin of Economics and Statistics, 52(May), 169-210.

[33] Luther, R., J. Matatko, and D. Corner, 1992, 'The Investment Performance of UK Ethical Unit Trust', Accounting Auditing \& Accountability Journal, 5(4), 57-70.

[34] MSCI Barra, 2010, 'MSCI Islamic Index Series Methodology', available at www.msci.com, last accessed March 2011.

[35] Naughton, S., and T. Naughton, 2000, 'Religion, Ethics and Stock Trading: The Case of an Islamic Equities Market', Journal of Business Ethics, 23(2), 145-159.

[36] Orlitzky, M., F. Schmidt, and S. Lynes, 2003, 'Corporate Social and Financial Performance: A Meta Analysis', Organization Studies, 24(3), 403-441.

[37] Sharpe, W. F., 1992, 'Asset Allocation: Management Style and Performance Measurement', Journal of Portfolio Management, 18(2), 7-19.

[38] Social Investment Forum, 2010, '2010 Report on Socially Responsible Investing Trends in the United States', available at www.socialinvest.org, last accessed March 2011.

[39] Sparkes, R., 2002, Socially Responsible Investment, a Global Revolution. John Wiley, Chichester.

[40] Usmani, M., 2002, An Introduction to Islamic Finance. Kluwer Law International, The Hague.

[41] Wilson, R., 1997, 'Islamic Finance and Ethical Investment', International Journal of Social Economics, 24(11), 1325-1342. 